\title{
Algorithm for the treatment of type 2 diabetes: a position statement of Brazilian Diabetes Society
}

\author{
Antonio C Lerario1, Antonio R Chacra², Augusto Pimazoni-Netto3,4, Domingos Malerbi5', Jorge L Gross6, \\ José EP Oliveira7, Marilia B Gomes*8, Raul D Santos ${ }^{9}$, Reine MC Fonseca10, Roberto Betti11 and Roberto Raduan ${ }^{12}$
}

\begin{abstract}
The Brazilian Diabetes Society is starting an innovative project of quantitative assessment of medical arguments of and implementing a new way of elaborating SBD Position Statements. The final aim of this particular project is to propose a new Brazilian algorithm for the treatment of type 2 diabetes, based on the opinions of endocrinologists surveyed from a poll conducted on the Brazilian Diabetes Society website regarding the latest algorithm proposed by American Diabetes Association /European Association for the Study of Diabetes, published in January 2009.

An additional source used, as a basis for the new algorithm, was to assess the acceptability of controversial arguments published in international literature, through a panel of renowned Brazilian specialists. Thirty controversial arguments in diabetes have been selected with their respective references, where each argument was assessed and scored according to its acceptability level and personal conviction of each member of the evaluation panel.

This methodology was adapted using a similar approach to the one adopted in the recent position statement by the American College of Cardiology on coronary revascularization, of which not only cardiologists took part, but also specialists of other related areas.
\end{abstract}

\section{Module 1}

Summary of Brazilian Diabets Society Members Opinions on the New ADA/EASD Algorithm

Considering the great controversy raised by the recommendations at the recent ADA/EASD algorithm, the Brazilian Diabetes Society (BDS) decided to evaluate the opinions of its members, through a survey conducted on the BDS' website during ten days, in November 2008 $[1,2]$. Two hundred and seventeen associates (endocrinologists) completed this survey.

Table 1 shows the percentages of answers to the proposed questions to BDS' associates.

\section{General conclusions about the survey results}

The results showed that the majority of the brazilian endocrinologists do not agree with the guidelines proposed by the ADA/EASD algorithm regarding the use of glitazone, GLP-1 analogs and DPP-IV inhibitors in the treatment of Type 2 Diabetes.

Considering the need for an algorithm reflecting the opinion of Brazilian endocrinologists, the Brazilian Dia- betes Society decided to develop this position statement, whose recommendations shall be dictated by the technical panel assessments, named by the entity and also by the results obtained from the survey.

\section{Module 2}

Results of the controversial diabetes argument acceptability assessment

In addition to the feedback from associates obtained through the survey and in order to provide a more robust basis to the algorithm proposed for the treatment of type 2 diabetes, the Brazilian Diabetes Society obtained the opinions of a panel formed by renowned Brazilian specialists regarding recommendations, guidelines and controversial arguments on the treatment of type 2 diabetes in international literature.

Thirty controversial arguments were individually assessed and scored on a 10-point scale by the evaluation panel members, who assigned individual scores $(0-10)$ to the 30 arguments presented, which were made into 5 acceptability levels (1-5).

*Correspondence: mariliabgomes@uol.com.br

8 Medicine School of State University of Rio de Janeiro, Rio de Janeiro, Brazil Full list of author information is available at the end of the article 


\begin{tabular}{|c|c|c|c|}
\hline \multirow[b]{2}{*}{ PROPOSED QUESTIONS } & \multicolumn{3}{|c|}{ ANSWERES' PERCENTAGES } \\
\hline & Yes & No & Others \\
\hline 1. Have you read the Treatment of Type 2 Diabetes algorithm proposed by ADA/EASD? & 90 & 10 & - \\
\hline $\begin{array}{l}\text { 2. Were you aware that the document expresses the opinion of a few authors and not of the entities } \\
\text { involved? }\end{array}$ & 77 & 23 & - \\
\hline 3. Do you intend to adopt the stages and steps suggested by this algorithm in your practice? & 51 & 49 & - \\
\hline $\begin{array}{l}\text { 4. Do you think that rosiglitazone-associated adverse events have been ratified in the medical literature of } \\
\text { excellence? }\end{array}$ & 36 & 64 & - \\
\hline $\begin{array}{l}\text { 5. Do you think that the cardiovascular protection assigned topioglitazone in that Position Statement is } \\
\text { real? }\end{array}$ & 34 & 66 & - \\
\hline $\begin{array}{l}\text { 6. Do you think that glitazone-associated adverse events (bone fracture and cardiovascular events) are } \\
\text { effects pertaining to this therapeutical class? }\end{array}$ & 49 & 21 & 30 \\
\hline $\begin{array}{l}\text { 7. Do you think that only GLP-1 analogs should be included in diabetes treatment excluding DPP-4 } \\
\text { inhibitors? }\end{array}$ & 13 & 69 & 18 \\
\hline $\begin{array}{l}\text { 8. Do you think that BDS' members have the expertise and the ability of criticism to issue a Position } \\
\text { Statement about this Algorithm? }\end{array}$ & 87 & 4 & 9 \\
\hline
\end{tabular}

The correlation between scores and their corresponding acceptability levels, as well as the analytical interpretation of results, are summarized in table 2 .

Average acceptability level of controversial matters assessed and their respective bibliographical references

Table S1, Additional file 1 shows the relation between controversial matters assessed and their respective bibliographical references and the average level of acceptability for each controversial matter, following the calculation methodology as defined in the previous item.

Table 2: Interpretation of acceptability levels of arguments based on individual scores

\begin{tabular}{ccc}
\hline Score & Acceptability Level & Interpretation \\
\hline $0-2$ & 1 & Full rejection \\
$3-4$ & 2 & Partial rejection \\
$5-6$ & 3 & Neutrality \\
$7-8$ & 4 & Partial acceptance \\
$9-10$ & 5 & Full acceptance \\
\hline
\end{tabular}

Module 3

New SBD algorithm proposal for the treatment of type 2 diabetes

Laboratory goals for characterization of good glycemic control

The desirable goal for $\mathrm{A} 1 \mathrm{C}$, as defined by the previous position statement in 2007, recommended A1C levels < 6.5\%. In this new Position Statement, the recommended A1C goal was redefined to $<7.0 \%$ as shown in table 3 . However, according to the ADA's 2010 statement, in patients with a history of severe hypoglycemia, patients with limited life expectancies, children, individuals with comorbidities, those with longstanding diabetes, advanced age and those with advanced microvascular or macrovascular complications" intensive glycemic control may outweigh its benefits. But for patients with short duration of diabetes, long life expectancy, and no significant CVD a level of A1c even lower than the general goal of $<7 \%$, has been suggested if this can be achieved without significant hypoglycemia or other adverse effects [35].

Regarding tolerable levels for laboratory goals, they were defined based on the recommendations contained in the bibliographical references [3-5]. 


\begin{tabular}{lll}
\hline Parameter & & Laboratory Targets \\
\cline { 2 - 3 } & \multicolumn{1}{c}{ Desirable Levels } & Tolerable Levels \\
\hline Glycated hemoglobin (A1C) & $<7 \%$ (in adults) & $\begin{array}{l}7.5-8.5 \%: 0-6 \text { years old1; } \\
<8 \%: 6-12 \text { years old } 1 ; \\
\end{array}$ \\
& & $<7.5 \%: 13-19$ years old $1 ;$ \\
Fasting glycemia & $<110 \mathrm{mg} / \mathrm{dL}$ & Up to $130 \mathrm{mg} / \mathrm{dL} 2$ \\
Pre-prandial glycemia & $<110 \mathrm{mg} / \mathrm{dL}$ & Up to $130 \mathrm{mg} / \mathrm{dL} 2$ \\
Post-prandial glycemia & $<140 \mathrm{mg} / \mathrm{dL}$ & Up to $180 \mathrm{mg} / \mathrm{dL} 2$ \\
\hline
\end{tabular}

New SBD algorithm proposal for treating type 2 diabetes

The new algorithm proposal for the treatment of type 2 diabetes was developed based on the premises and assessments conducted through the survey with SBD members and the assessment of conclusions from the panel of specialists (Table 4).

The presentation format of the new algorithm proposal was developed taking as fundamental reference the recommendations by the Joslin Diabetes Center \& Joslin Clinic and also by the American Association of Clinical Endocrinologists [6-9]..

The present algorithm was completed before the publication of the recent AACE/ACE algorithm [10]. As pointed out in the recent AACE algorithm safety, efficacy and effectiveness must be the priorities and in developing countries like Brazil cost of medications is an important barrier and could Influence the treatment.

\section{Module 4}

Summary of therapeutic profile of drugs used for treating type 2 diabetes

\section{Comparative efficacy and potential of A1C reduction of different therapeutic interventions}

The various therapeutic interventions present different levels of comparative efficacy and of potential of A1C reduction. Such facts must be taken into account when determining the best therapeutic strategy for each patient (table 5) [11,12].

\section{Summary of therapeutic profiles of drugs used for treating} type 2 diabetes

The main features of therapeutic profiles of drugs used for treating type 2 diabetes are summarized in table $6[13,14]$.

\section{Fixed combinations of oral antidiabetic drugs}

Due to its convenience and comparatively lower prices, fixed-combination therapies for treating diabetes are being made available more frequently. There are many presentations of combined treatments, including two oral agents in the same package, however with separate pills (table 7) or a single pill containing both active agents in the same formulation (table 8).

Action profile of human insulin and human insulin analogs

Basically, there are three commercial presentation forms of insulin in the Brazilian marketplace: 1) human insulin in monotherapy; 2) human insulin analog in monotherapy; 3) biphasic human insulin analogs.

The addition of insulin to patients with type 2 diabetes must be done as soon as the patient did not reach the target of HbA1c [15]. No definitve conclusions regarding the association between insulin therapy with glargine [16] and malignancies were established.

Table 9 summarizes the main features of the action profile of insulin preparations available.

Biphasic insulin analogs have a long-acting insulin component, in a formulation combined with a short-acting insulin component, as shown in table 10

\section{Module 5}

Treatment cost estimate for various therapeutic options

The concept of Evidence-Based Medicine recognizes three main components to help physicians define therapeutic conduct: the evidence of research per se, the clinical expertise of physicians and patient preferences. Treatment cost must be one of the fundamental factors for patients to fulfill their right of choice in due proportion, in the concept of evidence-based medicine [17].

We added two website suggestions for physicians to obtain information about drug costs for consumers of the therapeutic options they intend to prescribe. In both references, prices are displayed in different rows expressing the costs of each drug, considering the incidence of distinct tax rates, which vary according to Brazilian states. 
Table 4: Algorithm for the treatment of type 2 diabetes - 2009 update -

STAGE 1: INITIAL CONDUCT ACCORDING TO CURRENT CLINICAL CONDITION

\begin{tabular}{|c|c|c|c|}
\hline Mild manifestations & Moderate manifestations & Severe manifestations & $\begin{array}{c}\text { Hospitalization if glycemic } \\
\text { levels }>300 \mathrm{mg} / \mathrm{dL}\end{array}$ \\
\hline$\downarrow$ & $\downarrow$ & $\downarrow$ & $\downarrow$ \\
\hline $\begin{array}{l}\cdot \text { Glycemic levels }<200 \mathrm{mg} / \mathrm{dL} \\
+ \\
\text { - Mild symptoms or no symptoms } \\
+ \\
\text { - Absence of other acute concomitant } \\
\text { diseases }\end{array}$ & $\begin{array}{l}\text { - Any glycemic levels between } 200-300 \mathrm{mg} / \mathrm{dL} \\
+ \\
\text { - Absence of criteria for mild or severe } \\
\text { manifestations }\end{array}$ & $\begin{array}{l}\text { - Any glycemic levels above } 300 \mathrm{mg} / \mathrm{dL} \\
=\text { Or }= \\
\text { - Significant weight loss } \\
=\text { Or }= \\
\text { - Severe and significant symptoms } \\
=\text { Or }= \\
\text { - Presence of ketonuria }\end{array}$ & $\begin{array}{l}\text { Under the following conditions: } \\
\text { - Diabetic ketoacidosis and hyperosmolar state } \\
=\mathrm{Or}= \\
\text { - Intercurrent severe disease or comorbidity }\end{array}$ \\
\hline$\downarrow$ & $\downarrow$ & $\downarrow$ & $\downarrow$ \\
\hline $\begin{array}{l}\text { Metformin ( } 500 \mathrm{mg} / \text { day, intensifying up to } \\
2,000 \mathrm{mg} / \text { day) + lifestyle changes. } \\
\text { If patient does not reach A1C<7\% } \\
\text { in } 4-6 \text { weeks } \rightarrow \\
\text { Note: In case of metformin intolerance, } \\
\text { prolonged action formulations may be } \\
\text { useful. If the problem persists, choose one of } \\
\text { the options in Step } 2\end{array}$ & $\begin{array}{l}\text { Metformin ( } 500 \mathrm{mg} / \text { day, intensifying up to } \\
2,000 \mathrm{mg} / \text { day })+ \\
\text { lifestyle changes + other oral antidiabetic drugs } \\
\text { CRITERIA FOR INCLUDING SECOND OAD } \\
\downarrow\end{array}$ & Start insulin therapy immediately & $\begin{array}{l}\text { Start therapy according to the algorithm } \\
\text { recommendations and to glycemic control } \\
\text { obtained after discharge from hospital }\end{array}$ \\
\hline
\end{tabular}

STAGE 2: ADD OR MODIFY SECOND AGENT ACCORDING TO A1C LEVEL(*)

$\begin{array}{lll}7-8 \% & 8-10 \% & >10 \%\end{array}$

\begin{tabular}{lll}
\hline Sulphonylurea & Sulphonylurea & Insulin therapy \\
DPP-4 inhibitors & DPP-4 inhibitors & Basal insulin + prandial insulin \\
Glitazone & Glitazone & With of without \\
Glinides (prevalent post-prandial & Basal insulin (bedtime) & Metformin \\
hyperglycemia) & Exenatide (overweight or obesity) & Sulphonylurea \\
Acarbose (prevalent post-prandial & & iDPP-4 (studies currently being made) \\
hyperglycemia) & &
\end{tabular}

Exenatide (overweight or obesity) 
Table 4: Algorithm for the treatment of type 2 diabetes - 2009 update - (Continued)

$\left.{ }^{*}\right)$ In order to select the second agent, we suggest looking at therapeutic drug profiles in table 7.

MONITORING AND ADJUSTMENTS IN TREATMENT AFTER 2-3 MONTHS WITH MAXIMUM EFFECTIVE DOSAGE IN ORDER TO REACH GOALS: A1C <7\%, FASTING GLYCEMIA <130 mg/dL OR POST-PRANDIAL GLYCEMIA ( 2 HOURS) $<180 \mathrm{mg} / \mathrm{dL}$

\title{
STAGE 3: ADD A THIRD ORAL AGENT OR INTENSIFY INSULIN TREATMENT
}

Add a third oral agent with a different action mechanism. If in 2 or 3 months the targets of Intensify insulin therapy until the $\mathrm{A} 1 \mathrm{C}<7 \%$, fasting glycemia $<130 \mathrm{mg} / \mathrm{dL}$ or post-prandial A $1 \mathrm{C}<7 \%$, fasting glycemia $<130 \mathrm{mg} / \mathrm{dL}$ or post-prandial glycemia ( 2 hours) $<180 \mathrm{mg} / \mathrm{dL}$ are not glycemia ( 2 hours) $<180 \mathrm{mg} / \mathrm{dL}$ goals are reached.

reached, start insulin therapy.

$\rightarrow$

\section{INSTRUCTIONS AND ADDITIONAL COMMENTS}

1.Similarly to any other Guideline, this Algorithm contains general recommendations about the most highly indicated therapeutic options for each clinical situation. The choice of the best therapeutical plan must be made based on medical judgment, in patient's options and in treatment costs with the respective drugs.

2.For further information on the potential of $\mathrm{A} 1 \mathrm{C}$ level reduction of different drugs, please refer to table 6, in Module 4.

3.For further summarized information on therapeutic and usage safety profile of several drugs, please refer to table 7, in Module 4.

\author{
Abbreviations:
}

A1C = glycated hemoglobin; inhibitors ofDPP-4 (dipeptidyl peptidase-4 ); OAD = oral antidiabetic drugs. 
Table 5: Comparative efficacy of therapeutic interventions for reducing A1C levels

\begin{tabular}{cc}
\hline Strategy/Drug & Expected Reduction in A1C (\%) \\
\hline Weight reduction and increase in physical activity & $1.0-2.0$ \\
Metformin & $1.0-2.0$ \\
Insulin as additional therapy & $1.5-3.5$ \\
Sulfonylurea & $1.0-2.0$ \\
Glitazones & $0.5-1.4$ \\
GLP1 Agonists & $0.5-1.0$ \\
DPP-4 Inhibitors & $0.5-0.8$ \\
Alpha-glycosidase Inhibitors & $0.5-0.8$ \\
Glinides & $0.5-1.5$ \\
\hline
\end{tabular}

For the physician, the desired piece of information is the maximum retail price (MRP), which may be found in the last row to the right in price tables.

\section{Links to browse drug prices}

http://portal2.saude.gov.br/BPS/visao/consultapublica/

publico interno item.cfm $[18]$
Using the internal resource of research to obtain the desired price http://www.elomedico.com.br[19]

Requires previous and free subscription. Search for item "drugs/prices" on the left row in the homepage

\section{Table 6: Pharmacologic options for oral DM-2 treatment}

\begin{tabular}{|c|c|}
\hline DRUG & PROFILE AND ACTION MECHANISM \\
\hline Acarbose (Glucobay ${ }^{\circledR}$ ) & $\begin{array}{l}\text { Slows down intestinal glucose absorption. Low potential of A1C reduction ( } 0.5-0.8 \%) \text {. } \\
\text { Gastrointestinal intolerance. }\end{array}$ \\
\hline Metformin (Glifage ${ }^{\circledR}$, others) & $\begin{array}{l}\text { Reduces primarily the hepatic glucose production and fights insulin resistance. High potential of } \\
\text { A1C reduction ( } 2 \%) \text {. Gastrointestinal intolerance. Does not cause hypoglycemia. May promote mild } \\
\text { weight loss. Contraindicated in case of renal dysfunction. }\end{array}$ \\
\hline $\begin{array}{l}\text { Glitazones } \\
\left.\text { - Rosiglitazone (Avandia }{ }^{\circledR}\right) \\
\text { - Pioglitazone }\left(\text { Actos }^{\circledR}\right)\end{array}$ & $\begin{array}{l}\text { Primarily fight insulin resistance and reduces hepatic glucose production. Increases muscle, fatty } \\
\text { tissue and liver sensitivity to insulin. Intermediate A1C reduction potential ( } 0.5-1.4 \%) \text {. Promote } \\
\text { hydric retention and weight gain, increasing the risk of heart failure. Also increase the risk of } \\
\text { fracture. Recent results of studies such as RECORD and BARI 2D indicate that rosiglitazone does not } \\
\text { increase the risk of infarction and CVD. }\end{array}$ \\
\hline $\begin{array}{l}\text { Sulfonylureas } \\
\left.\text { - Glimepiride (Amaryl }{ }^{\circledR}\right) \\
\text { - Glibenclamide (Daonil }{ }^{\circledR} \text { ) } \\
\text { - Gliclazide (Diamicron } \mathrm{MR}^{\circledR} \text { ) } \\
\text { - Others }\end{array}$ & $\begin{array}{l}\text { Stimulate endogenous insulin production by pancreatic beta cells, with pharmacological action } \\
\text { medium to long ( } 8-24 \text { hours). Useful to control fasting glycemia and } 24 \text {-hour glycemia. High } \\
\text { potential of A1C reduction ( } 2 \% \text { ). May cause hypoglycemia. Glibenclamide has higher risk of } \\
\text { hypoglycemia. An alleged deleterious action on human beta cells has not yet been confirmed. }\end{array}$ \\
\hline $\begin{array}{l}\text { Glinides } \\
\text { - Repaglinide (Novonorm }{ }^{\circledR} \\
\text { Prandin } \\
{ }^{\circledR} \text { ) } \\
\text { - Nateglinide }\left(\text { Starlix }^{\circledR}\right)\end{array}$ & $\begin{array}{l}\text { Stimulate endogenous insulin production by pancreatic beta cells, with short duration (1-3 hours). } \\
\text { Useful to control post-prandial hyperglycemia. Intermediate potential of A1C reduction (1.0 - } \\
1.5 \%) \text {. May promote weight gain and hypoglycemia. Repaglinide is more powerful than } \\
\text { nateglinide. }\end{array}$ \\
\hline $\begin{array}{l}\text { Incretin mimetics and DPP-4 } \\
\text { inhibitors } \\
\text { - Exenatide (Byetta }{ }^{\circledR} \text { ) } \\
\text { - Vildagliptin (Galvus }{ }^{\circledR} \text { ) } \\
\text { - Sitagliptin (Januvia }{ }^{\circledR} \text { ) }\end{array}$ & $\begin{array}{l}\text { This is a new therapeutic class for treating diabetes, whose mechanism includes stimulating beta } \\
\text { cells to increase insulin synthesis and action on pancreatic alpha cells, reducing glucagon } \\
\text { production. Glucagon has the effect of increasing glycemic levels. Average potential of A1C } \\
\text { reduction ( } 0.5-0.8 \% \text {, depending on the basal A1C value). Do not cause hypoglycemia but } \\
\text { gastrointestinal intolerance and pancreatitis have been described (exenatide and sitaglipitn) } \\
{[13,14] \text {. }}\end{array}$ \\
\hline
\end{tabular}

This table represents only a partial relation of commercial medications of various drugs and does not represent a specific recommendation of any commercial brand. 
Table 7: Partial list of oral antidiabetic drugs used in combination therapy: two substances in separate pills

\begin{tabular}{|c|c|c|c|}
\hline Therapeutic classes & Chemical Denomination & Commercial Denomination & Action and Dosage Mechanism \\
\hline $\begin{array}{c}\text { sulffonylurea } \\
+ \\
\text { biguanide }\end{array}$ & $\begin{array}{c}\text { glimepiride } \\
+ \\
\text { metformin }\end{array}$ & $\begin{array}{l}\text { Amaryl Flex } \\
\text { Sanofi-Aventis }\end{array}$ & $\begin{array}{l}\text { Long acting secretagogue of insulin } \\
\text { (glimepiride) + peripheral action insulin } \\
\text { sensitizer (metformin). } \\
\text { Dosage: glimepiride - } 1 \mathrm{mg} \text { and } 2 \mathrm{mg}+ \\
\text { metformin - } 500 \mathrm{mg} \text {. }\end{array}$ \\
\hline $\begin{array}{c}\text { glinide } \\
+ \\
\text { biguanide }\end{array}$ & $\begin{array}{c}\text { nateglinide } \\
+ \\
\text { metformin }\end{array}$ & $\begin{array}{l}\text { Starform } \\
\text { Novartis }\end{array}$ & $\begin{array}{l}\text { Short-acting secretagogue of insulin } \\
\text { (nateglinide) + peripheral action insulin } \\
\text { sensitizer (metformin). } \\
\text { Dosage: nateglinide - } 120 \mathrm{mg}+\text { metformin - } \\
500 \mathrm{mg} \text { and } 850 \mathrm{mg} \text {. }\end{array}$ \\
\hline
\end{tabular}

This table presents only a partial list of commercial medications of various drugs and does not represent a specific recommendation of any commercial brand.

Table 8: Partial relation of oral antidiabetic drugs at combination therapy: two substances in a single pill

\begin{tabular}{|c|c|c|c|}
\hline Therapeutic classes & Chemical Denomination & Commercial Denomination & Action and Dosage Mechanism \\
\hline $\begin{array}{c}\text { biguanide } \\
+ \\
\text { sulphonylurea }\end{array}$ & $\begin{array}{c}\text { metformin } \\
+ \\
\text { glibenclamide }\end{array}$ & $\begin{array}{c}\text { Glucovance }^{\bullet} \\
\text { Merck }\end{array}$ & $\begin{array}{l}\text { Peripheral action insulin sensitizer } \\
\text { (metformin) + long-acting secretagogue of } \\
\text { insulin (glibenclamide). } \\
\text { Dosage: } \\
250 \mathrm{mg} \text { metformin }+1.25 \mathrm{mg} \text { glibenclamide } \\
500 \mathrm{mg} \text { metformin }+2.5 \mathrm{mg} \text { glibenclamide } \\
500 \mathrm{mg} \text { metformin }+5 \mathrm{mg} \text { glibenclamide. }\end{array}$ \\
\hline $\begin{array}{c}\text { glitazone } \\
+ \\
\text { biguanides }\end{array}$ & $\begin{array}{c}\text { rosiglitazone } \\
+ \\
\text { metformin }\end{array}$ & $\begin{array}{c}\text { Avandamet } \\
\text { Glaxo }\end{array}$ & $\begin{array}{l}\text { Combination of two peripheral action insulin } \\
\text { sensitizers, with different action } \\
\text { Dosage: } \\
2 \mathrm{mg} \text { rosiglitazone }+500 \mathrm{mg} \text { metformin } \\
4 \mathrm{mg} \text { rosiglitazone }+500 \mathrm{mg} \text { metformin. }\end{array}$ \\
\hline $\begin{array}{c}\text { Incretin mimetic } \\
+ \\
\text { metformin }\end{array}$ & $\begin{array}{c}\text { sitagliptin } \\
+ \\
\text { metformin }\end{array}$ & $\begin{array}{l}\text { Janumet }^{\circ} \\
\text { MSD }\end{array}$ & $\begin{array}{l}\text { DPP-4inhibitor + peripheral action insulin } \\
\text { sensitizer (metformin). } \\
\text { Dosage: } \\
50 \text { mg sitagliptin }+500 \text {, } \\
850 \text { or } 1,000 \text { mg metformin }\end{array}$ \\
\hline $\begin{array}{c}\text { Incretin mimetic } \\
+ \\
\text { metformin }\end{array}$ & $\begin{array}{c}\text { vildagliptin } \\
+ \\
\text { metformin }\end{array}$ & $\begin{array}{l}\text { Galvus Met }^{\circ} \\
\text { Novartis }\end{array}$ & $\begin{array}{l}\text { DPP-4 inhibitor + peripheral action insulin } \\
\text { sensitizer (metformin). } \\
\text { Dosage: } \\
50 \mathrm{mg} \text { vildagliptin }+ \\
500,850 \text { or } 1,000 \mathrm{mg} \text { metformin }\end{array}$ \\
\hline
\end{tabular}

This table presents only a partial list of commercial medications of various drugs and does not represent a specific recommendation of any commercial brand. 
Table 9: action profile of human insulin and human insulin analogs

\begin{tabular}{|c|c|c|c|c|}
\hline $\begin{array}{l}\text { Human } \\
\text { Insulins }\end{array}$ & Insulin Type & Onset & Action peak & Duration of action \\
\hline \multirow[t]{3}{*}{ Rapid-acting insulin analogs } & $\begin{array}{l}\text { Glulisine } \\
\text { (Apidra") }\end{array}$ & $<5-15$ minutes & 1 hour & 4 hours \\
\hline & $\begin{array}{l}\text { Lispro } \\
\text { (Humalog })\end{array}$ & $<15$ minutes & $0.5-1.5$ hour & 2-4 hours \\
\hline & $\begin{array}{c}\text { Aspart } \\
(\text { NovoRapid })^{\circ}\end{array}$ & 5-10 minutes & $1-3$ hours & 3-5 hours \\
\hline Short acting insulin & $\begin{array}{c}\text { Regular } \\
\left(\text { Novolin }^{\circ} \text { R, Humulin }{ }^{\circ} \text { R) }\right.\end{array}$ & $30-60$ minutes & $2-3$ hours & $3-6$ hours \\
\hline Intermediate acting insulin & NPH (Novolin ${ }^{\circ}$ Humulin $\left.{ }^{\circ} \mathrm{N}\right)$ & 2-4 hours & 4-10 hours & $10-16$ hours \\
\hline \multirow[t]{2}{*}{ Long-acting insulin analogs } & $\begin{array}{l}\text { Glargine } \\
\text { (Lantus }{ }^{\circ}\end{array}$ & $1-2$ hours & None & Up to 24 hours \\
\hline & $\begin{array}{l}\text { Detemir } \\
\text { (Levemir })\end{array}$ & $1-2$ hours & None & Up to 24 hours \\
\hline
\end{tabular}

This table presents only a partial list of commercial medications of various drugs and does not represent a specific recommendation of any commercial brand.

\section{Table 10: Biphasic rapid and long-acting insulin analogs}

\begin{tabular}{|c|c|c|}
\hline $\begin{array}{l}\text { Insulin aspart and protaminated (70\%) + insulin } \\
\text { aspart (30\%) }\end{array}$ & NovoMix $70 / 30$ & $\begin{array}{l}\text { Pre-mix with } 70 \% \text { long-acting insulin aspart (up to } 24 \text { hours) } \\
+30 \% \text { aspart insulin of immediate release, short acting (4-6 } \\
\text { hours), to control post-prandial and interprandial glycemic } \\
\text { levels }\end{array}$ \\
\hline $\begin{array}{l}\text { Neutral protamine insulin lispro }(75 \%)+\text { insulin } \\
\text { lispro }(25 \%)\end{array}$ & $\begin{array}{l}\text { Humalog } \\
25\end{array}$ & $\begin{array}{l}\text { Pre-mix with } 75 \% \text { intermediate acting insulin NPL (up to } 24 \\
\text { hours) }+25 \% \text { insulin of immediate release, short-acting (4-5 } \\
\text { hours), to control post-prandial and interprandial glycemic } \\
\text { levels }\end{array}$ \\
\hline $\begin{array}{l}\text { Neutral protamine insulin lispro }(50 \%)+\text { insulin } \\
\text { lispro }(50 \%)\end{array}$ & $\begin{array}{l}\text { Humalog }{ }^{\oplus} \text { Mix } \\
50\end{array}$ & $\begin{array}{l}\text { Pre-mix with } 50 \% \text { intermediate acting insulin NPL (up to } 24 \\
\text { hours) }+50 \% \text { insulin of immediate release, short-acting (4-5 } \\
\text { hours), to control post-prandial and interprandial glycemic } \\
\text { levels }\end{array}$ \\
\hline
\end{tabular}

This table presents only a partial list of commercial medications of various drugs and does not represent a specific recommendation of any commercial brand.

\section{Additional material}

Additional file $\mathbf{1}$ Table $\mathbf{S 1}$. average acceptability level of controversia matters assessed and their respective bibliographic references.

\section{Competing interests}

$A C L$ - The author declare that he has no competing interest

ARC - Research grants from Eli Lilly, Sanofi-Aventis, Roche, Novartis, MSD, Novo Nordisk

Advisory board: AZ, BMS, Sanofi-Aventis, Novo Nordisk

APN - External Medical Consultant for Roche Diagnostics; Speaker GSK, Eli Lily

DM - Committee Member: NONE

Research Grant: NONE

Speakers' Bureau: SANOFI-AVENTIS

Honoraria: SANOFI-AVENTIS

Expert Witness: NONE

Stock Ownership: NONE

Board of Directors: NONE

Consultant:: NONE
Scientific Advisory Board: SANOFI-AVENTIS

Steering Committee: NONE

JLG - Research Grants: Abbott, Bristol-Myers Squibb, Eli Lilly, Glaxo Smith Kline, Merck Sharp \& Dohme, Novo Nordisk, Pfizer, Roche, Sanofi-Aventis

Speaker: Bristol-Myers Squibb, Eli Lilly, Glaxo Smith Kline, Merck Sharp \& Dohme, Novo Nordisk, Sanofi-Aventis

Member Advisory Board: Glaxo Smith Kline, Merck Sharp \& Dohme, Novo Nordisk, Sanofi-Aventis

JEPO - Member Advisory Board Sanofi-Aventis

MBG - The author declare that she has no competing interest

RDS - Member Advisory Board GSK, MerckSharp\&Dhome

Speaker: Astra Zeneca, Pfizer, MerckSharp\&Dhome, Bristol Meyers Squibb, GSK,

Novartis

RMCF - The author declare that she has no competing interest

$\mathrm{RB}$ - The author declare that he has no competing interest

RR - Member Advisoy board Lantus

Speaker: SanofiAventis, Abbott, MerckSharp\&Dhome, Eli Lily, Novonordisk, GSK

Authors' contributions

APN wrote the manuscript. 
MBG partipated in the design of the study and wrote the manuscript. $A C L, A R C, D M, J L G$, JEPO, RDS, RMCF, RB, RR: all have partipated in the technical panel.

All authors read and approved the final manuscript.

\section{Author Details}

${ }^{1}$ Medicine School of Universidade São Paulo, InCor - HCFMUSP Diabetes Core Sao Paulo, Brazil, 2Paulista Medicine School at Universidade Federal São Paulo UNIFESP, Sao Paulo, Brazil, 3integrated Center of Cardiovascular Hypertension and Metabology at the Kidney and Hypertension Hospital at Universidade Federal de São Paulo, São Paulo, Brazil, ${ }^{4}$ Diabetes Center of Hospital Alemão Oswaldo Cruz, in Sao Paulo, Brazil, 5University of Sao Paulo Medical School. Sao Paulo, Brazil, ${ }^{\circ}$ Medical School at Universidade Federal Rio Grande do Sul and Hospital Clínicas in Porto Alegre, Porto Alegre, Brazil, ${ }^{7}$ Medicine School of Universidade Federal Rio de Janeiro and Division of Nutrology and Diabetes Service at UFRJ Hospital Universitário Clementino Fraga Filho, Rio de Janeiro, Brazil, 8 Medicine School of State University of Rio de Janeiro, Rio de Janeiro, Brazil, ${ }^{9}$ nCor Lipid Clinical InCor - HCFMUSP, Sao Paulo, Brazil, ${ }^{10}$ Universidade Federal da Bahia - UFBA, Salvador, Brazil, "'Diabetes Core. InCor- HCFMUSP and Diabetes Center of Hospital Alemão Oswaldo Cruz, Sao Paulo, Brazil and

${ }^{12}$ Internal Medicine Service at Beneficencia Portuguesa, Sao Paulo, Brazil

Received: 14 December 2009 Accepted: 8 June 2010

Published: 8 June 2010

\section{References}

1. Patel MR, Dehemer GJ, Hirshfeld JW, Smith PK, Spertus JA: ACCF/SCAI/ STS/AATS/AHA/ASNC 2009 Appropriateness Criteria for Coronary Resvascularization. J Am Coll Cardio/ 2009, 53(6530-553 [http:// content.onlinejacc.org/cgi/reprint/j.jacc.2008.10.005v1.pdf].

2. Gomes MB: Enquete sobre Algoritmo American Diabetes Association/ European Association for the Study of Diabetes - December 2008 - 217 SBD Associates. [http://www.diabetes.org.br/agenda/comunicados/ index.php?id=1838]. Accessed on 07/13/09

3. Grupo Interdisciplinar de Padronização da Hemoglobina Glicada - A1C: Atualização sobre Hemoglobina Glicada (A1C) para Avaliação do Controle Glicêmico e para o Diagnóstico do Diabetes: Aspectos Clínicos e Laboratoriais. Posicionamento Oficial $3^{a}$ Edição. Brazilian Diabetes Society, Brazilian Endocrinology and Metabolim Society, Brazilian Clinical and Pathology Society, National Diabetes Federation 2009.

4. American Diabetes Association: Standards of Medical Care in Diabetes 2009. Diabetes Care 2010, 32(Suppl 1):S16-S61.

5. Pignone M: Decisions about intensity of glycemic control should depend on age and functional status. Clinical Diabetes 2009, 27:147-8.

6. Joslin Diabetes Center \& Joslin Clinic: Clinical Guideline for Pharmacological Management of Type 2 Diabetes, 2007. [http:// www.joslin.org/Files/Pharm ClinGuide9706final.pdf]. Accessed on 07/13/ 09

7. Joslin Diabetes Center \& Joslin Clinic: Clinical guideline for adults with diabetes,2009. [http://www.joslin.org/Files/

Adult guidelines 041109 grade updating.pdf]. Accessed on 07/13/09

8. Blonde L, Einhorn D, Grunberger G, Handelsman $Y$, Hellsman $Y$, Hellman $R$, Lebovitz H, Levy P, Roberts VL, for the ACE/AACE Diabetes Road Map Task Force, et al:: Road Maps to Achieve Glycemic Control in Type 2 Diabetes Mellitus. Endocrine Practice 2007, 13(3260-261 [http://www.aace.com/ pub/roadmap/Diabetes Roadmap.ppt]. Accessed on 13/02/2010

9. Rodbard HW, Blonde L, Braithwaite SS, Brett EM, Cobin RH, Handelsman Y, Hellman R, Jellinger PS, Jovanovic LG, Levy P, Mechanick J, Zangeneh F, AACE Diabetes Mellitus Clinical Practice Guidelines Task Force: American Association of Clinical Endocrinologists medical guidelines for clinical practice for the management of diabetes mellitus. Endocr Pract 2007, 13(Suppl11-68 [http://www.aace.com/pub/pdf/quidelines/ DMGuidelines2007.pdf].

10. Rodbard HW, Jellinger PS, Davidson JA, Einhorn D, Garber A, Grunberger G, Handelsman Y, Horton ES, Lebovitz H, Levy P, Moghissi ES, Schartz SS: Statement by an American Association of Clinical Endocrinologists/ American College of Endocrinology Consensus Panel on type 2 diabetes mellitus:an algorithm for glycemic control. Endocrine Practice 2009, 15:540-559.

11. Grant RW: How Doctors Choose Medications to Treat T2DM. Diabetes Care 2007, 30:1448-1453.
12. Nathan DM, Buse JB, Davidson MB, Heine RJ, Holman RR, Sherwin R, Zinman B: Medical Management of Hyperglycemia in Type 2 Diabetes: A Consensus Algorithm for the Initiation and Adjustment of Therapy. Diabetes Care 2009, 32:193-20

13. Matveyenko AV, Dry S, Cox HI, Moshtahian A, Gurlo T, Galasso R, Butler AE, Butler PC: Beneficial endocrine but adverse exocrine effects of sitaglipitinin the HIP rat model of type 2 diabetes, interactions with metformin. Diabetes 2008, 58:1604-1615.

14. Nachani JS, Bulchadani DG, Nookala A, Herndon B, Molteni A, Pandya P, Taylor R, Weide L, Alba LM: Biochemical and histological effects of exendin-4(exenatide) on the rat pancreas. Diabetologia 2010, 53:153-159.

15. McMahon GT, Dlhy RG: Intention to Treat -- Initiating Insulin and the 4-T Study. NEng/ J Med 2000, 357(17):1759-61. 17

16. Hemkens LG, Grouven U, Bender R, Günster C, Gutschmidt S, Selke GW Sawicki PT: Risk of malignancies in patients with diabetes treated with human insulin or insulin analogues: a cohort study. Diabetologia 2009, 52:1732-44

17. Deyo JP; "Ramsey RA: Evidence-Based Clinical Practice: Concepts and Approaches. Butterworth-Heinemann. Boston, USA; 2000.

18. Lista de Preços de Medicamentos [http://portal2.saude.gov.br/BPS/ visao/consultapublica/publico interno item.cfm]. Accessed on 03/20/ 2010

19. Lista de preços de medicamentos. Portal Elomédico [http:// www.elomedico.com.br]. Accessed on 07/13/09

doi: 10.1186/1758-5996-2-35

Cite this article as: Lerario et al., Algorithm for the treatment of type 2 diabetes: a position statement of Brazilian Diabetes Society Diabetology \& Metabolic Syndrome 2010, 2:35

\section{Submit your next manuscript to BioMed Central and take full advantage of:}

- Convenient online submission

- Thorough peer review

- No space constraints or color figure charges

- Immediate publication on acceptance

- Inclusion in PubMed, CAS, Scopus and Google Scholar

- Research which is freely available for redistribution
C Biomed Central 